\title{
Correlation between the functional impairment of bone marrow-derived circulating progenitor cells and the extend of coronary artery disease
}

Ilkay Bozdag-Turan ${ }^{1 * \dagger}$, R Goekmen Turan ${ }^{1 * \dagger}$, Liliya Paranskaya', Nicole S Arsoy', C Hakan Turan', Ibrahim Akin ${ }^{1}$, Stephan Kische', Jasmin Ortak', H Schneider', S Ludovicy', Tina Hermann'1, Giuseppe D'Ancona', Serkan Durdu², A Ruchan Akar ${ }^{2}$, Hueseyin Ince ${ }^{1}$ and Christoph A Nienaber ${ }^{1}$

\begin{abstract}
Background: Bone marrow-derived circulating progenitor cells (BM-CPCs) in patients with coronary heart disease are impaired with respect to number and functional activity. However, the relation between the functional activity of BM-CPCS and the number of diseased coronary arteries is yet not known. We analyzed the influence of the number of diseased coronary arteries on the functional activity of BM-CPCs in peripheral blood (PB) in patients with ischemic heart disease (IHD).

Methods: The functional activity of BM-CPCs was measured by migration assay and colony forming unit in 120 patients with coronary 1 vessel $(I H D 1, n=40)$, coronary 2 vessel $(I H D 2, n=40)$, coronary 3 vessel disease (IHD3, $n=40)$ and in a control group of healthy subjects $(n=40)$. There was no significant difference of the total number of cardiovascular risk factors between IHD groups, beside diabetes mellitus (DM), which was significantly higher in IHD3 group compared to IHD2 and IHD1.
\end{abstract}

Results: The colony-forming capacity (CFU-E: $p<0.001$, CFU-GM: $p<0.001$ ) and migratory response to stromal cellderived factor 1 (SDF-1: $p<0.001$ ) as well as vascular endothelial growth factor (VEGF: $p<0001$ ) of BM-CPCs were reduced in the group of patients with IHD compared to control group. The functional activity of BM-CPCs was significantly impaired in patients with IHD3 as compared to IHD1 (VEGF: $p<0.01$, SDF-1: $p<0.001$; CFU-E: $p<0.001$, CFU-GM: $p<0.001$ ) and to IHD2 (VEGF: $p=0.003$, SDF-1: $p=0.003$; CFU-E: $p=0.001$, CFU-GM: $p=0.001$ ). No significant differences were observed in functional activity of BM-CPCs between patients with IHD2 and IHD1 (VEGF: $p=0.8$, SDF-1: $p=0.9 ;$ CFU-E: $p=0.1, C F U-G M: p=0.1$ ). Interestingly, the levels of haemoglobin Alc (HbAlc) correlated inversely with the functional activity of BM-CPCS (VEGF: $p<0.001, r=-0.8$ SDF-1: $p<0.001, r=-0.8$; CFU$E: p=0.001, r=-0.7$, CFU-GM: $p=0.001, r=-0.6)$ in IHD patients with DM.

Conclusions: The functional activity of BM-CPCS in PB is impaired in patients with IHD. This impairment increases with the number of diseased coronary arteries. Moreover, the regenerative capacity of BM-CPCs in ischemic tissue further declines in IHD patients with DM. Furthermore, monitoring the level of BM-CPCs in PB may provide new insights in patients with $\mathrm{HD}$.

Keywords: Circulating progenitor cells, Migration capacity, Colony forming capacity, Ischemic heart disease, Diabetes, Coronary artery disease

\footnotetext{
* Correspondence: ilkayboztur@googlemail.com; dr_g_turan@hotmail.com

${ }^{\dagger}$ Equal contributors

'Department of Internal Medicine, Division of Cardiology, University hospital Rostock, Ernst Heydemann Str 6, Rostock 18055, Germany

Full list of author information is available at the end of the article
} 


\section{Background}

Circulating progenitor cells (CPCs) are primitive bone marrow cells (BMCs), that have the capacity to proliferate, migrate, and differentiate into various mature cell types. [1-3] Furthermore, these cells circulate in peripheral blood, and implicate in neoangiogenesis after tissue ischemia. [4-6] Experimental studies have shown that reintroduction of cytokines such as vascular endothelial growth factor (VEGF), angiopoetin-1, SDF-1, G-CSF, or GM-CSF enhance the mobilization of the BM-CPCs to the ischemic myocardium, augmenting neovascularization. $[7,8]$ It has been suggested that cardiovascular risk factors (CVRFs) are associated with reduction of functional activity of BM-CPCs in patients with coronary artery disease as well as in healthy men. $[9,10]$ Moreover, especially diabetes has been shown to reduce numbers and impair functional activity of BM-CPCs. [11-13] However, it is unknown whether the functional activity of BM-CPCs relates to the number of diseased coronary arteries in patients with IHD. In this study, we analyzed the functional activity of BM-CPCs and their relationship with the number of diseased coronary arteries in IHD-patients.

\section{Methods}

\section{Study protocol and study population}

132 IHD patients between 18-80 years of age were screened for inclusion in this study, if they had had a documented MI at least 6 months ago and had left ventricular dysfunction. 12 of 132 patients had to be excluded from the study due to acute coronary syndrom and/or acutely decompensated heart failure. All 120 IHD patients underwent diagnostic cardiac catheterization due to stable angina. We selected a control group of 40 healthy subjects without overt heart disease and/or major cardiovascular risk factors such as diabetes, smoking, hypertension, hypercholesterolemia, and positive family history concerning IHD. All of them had atypical chestpain but no evidence of cardiac ischaemia. Control subjects underwent coronary angiography to rule out ischaemic heart disease within 24 hours after admission. The patients were recruited during diagnostic cardiac catheterization by interventional cardiologist and were separated into 4 groups (I) IHD1; II) IHD2; III) IHD3 and IV) Control group). After this step a peripheral blood sample was taken during cardiac catheterization to measure functional activity and characterization of $\mathrm{BM}-\mathrm{CPCs}$ before any interventional procedure. A CVRFs score including age $>40$ years, male sex, hypertension, diabetes, smoking, positive family history and hypercholesterolaemia was calculated according to Vita et al. [14] Hypertension was defined as a history of hypertension for $>1$ year that required the initiation of antihypertensive therapy by the primary physician.
Smoking was defined as patients revealing a history of smoking for $>2$ pack-years and current smoking. Positive family history was defined as documented evidence of coronary artery disease (CAD) in a parent or sibling before 60 years of age. Hypercholesterolaemia was defined as fasting low-density-lipoprotein (LDL) cholesterol levels exceeding $130 \mathrm{mg} / \mathrm{dl}$. Diabetes was defined as the need for oral antidiabetic drug therapy or insulin use.

Exclusion criteria were the presence of acutely decompensated heart failure with a New York Heart Association (NYHA) class of IV, infectious or inflammatory disease, surgery or trauma within 2 months, renal or liver dysfunction, thrombocytopenia, anemia, severe comorbidity and alcohol or drug dependency, history of other severe chronic diseases or cancer, or unwillingness to participate. The study conforms with the principles outlined in the Declaration of Helsinki and was approved by the local ethics committee. Written informed consent was obtained from each patient.

\section{Coronary angiography and left ventriculography}

All IHD patients underwent left heart catheterization, left ventriculography and coronary angiography. Cardiac catheterization was performed according to the guidelines for coronary angiography of the American College of Cardiology and the American Heart Association. [15] Cardiac function was determined by left ventriculography. Cardiac function was evaluated by global EF. Global EF was measured with Quantcor software (Siemens, Erlangen/Germany). The extent of coronary artery disease was scored, by at least two independent interventional cardiologists, as 0 (stenosis $<50$ percent), 1 (stenosis of any main coronary artery $>50$ percent), 2 (stenosis of two main coronary arteries $>50$ percent), and 3 (stenosis of three main coronary arteries $>50$ percent).

\section{Phenotypic characterization of BM-CPCs}

Phenotypic characterization of BM-CPCs were performed in 5 of $20 \mathrm{ml}$ peripheral blood (PB) for CD34/45 ${ }^{+}$and CD133/45 ${ }^{+}$by flow cytometry (EPICS-XL, Beckmann Coulter).

Samples were stained with fluorescein isothiacyanate (FITC) conjugate of a $\mathrm{CD}^{+} 5^{+}$antibody (clone J33, Coulter/Immunotech, Marseille/France) that detects all isoforms and glycoforms of the CD45 family, phycoerythrin (PE) conjugate of a CD34 ${ }^{+}$antibody (clone 581, Coulter/Immunotech, Marseille/France) that detects a class III epitope on all glycoforms of the CD34 ${ }^{+}$antigen and PE conjugate of a CD133/1 $1^{+}$(Miltenyi Biotec, Bergisch Gladbach/Germany). Control samples were stained with $\mathrm{CD} 45^{+}$FITC and an IgG1 PE (Coulter/Immunotech, Marseille/France) isotype. 
For each patient EDTA blood samples were labelled with CD34/45 $5^{+} \mathrm{CD} 133 / 45^{+}$, and IgG1/CD45. All tubes were incubated at room temperature in the dark. After incubation, cells were lysed with ammonium chloride, washed with phosphate-buffered saline (PBS). Samples were then stored on ice at $4{ }^{\circ} \mathrm{C}$ in dark environment for 20 minutes and analysed by flow cytometry.

Samples were subjected to a 2D side scatterfluorescence dot plot analysis. After appropriate gating, the concentration of BM-CPCs with low cytoplasmic granularity (low side ward scatter) was quantified and expressed as concentration of cells per million white blood cells.

\section{Isolation and cultivation of BM-CPCs}

$20 \mathrm{ml}$ peripheral venous blood was taken using a BD Vacutainer $\mathrm{CPT}^{\mathrm{TM}}$ from each patient. BM-CPCs were isolated by density gradient centrifugation. After 2 washing steps, cells were resuspended in $1 \mathrm{ml} \mathrm{EBM2-medium}$ (Cell system). The number of isolated BM-CPCs were determined in a Neubauer chamber.[10,16]

\section{Assessment of migration assay}

A total of $1 \times 10^{6}$ BM-CPCs were resuspended in $250 \mu \mathrm{X}$ Vivo and placed in the top compartment of a Boyden Chamber. This chamber was placed in a 24-well culture dish contained either only EBM-2 medium or $100 \mathrm{ng} / \mathrm{ml}$ stromal cell derived factor-1 (SDF-1) or $100 \mathrm{ng} / \mathrm{ml}$ vascular endothelial growth factor (VEGF) in EBM2-medium. After 24 hours of incubation at $37^{\circ} \mathrm{C}$ transmigrated cells were counted by 2 independent investigators. [10,16] Quantitative evaluation of migrated cells to SDF-1 and VEGF were analyzed in comparison to cells without chemokine in blood samples of both groups. Values are expressed as \% of migrated cells without chemokine.

\section{Assessment of colony forming unit assay}

$1 \times 10^{5}$ in BM-CPCs per $\mathrm{ml}$ were seeded in Methocult GF H4435 (Stemcell Technologies). Culture dishes were seeded with $1 \mathrm{ml}$ cell suspension and then incubated at $37^{\circ} \mathrm{C}$. Colony-forming unit erythroid (CFU-E) and CFUgranulocyte/macrophage (CFU-GM) were studied under phase-contrast microscopy and were counted after 14 days of incubation by 2 independent investigators. [16]

\section{Biochemical measurements}

Peripheral blood was collected from patients with IHD and control group on day 1 of admission. Serum creatine phosphokinase (CPK) values (normal range: 24-195 U/ l), inflammatory markers such as $C$ - reactive protein (normal range $<0.5 \mathrm{mg} / \mathrm{dl}$ ) and leukocytes (normal range: $4-12 \times 10^{3} / \mu \mathrm{l}$ ) and routine laboratory tests with HbA1C were measured in the study population.

\section{Statistical analysis}

Continuous data are presented as mean \pm SD. Comparison of the distributions of a continuous variable between two independent groups was performed using the twosided nonparametric Mann-Whitney test. The type I error rate $\alpha$ was chosen as $5 \%$ and two-sided p-values equal or less 0.05 were interpreted as statistically significant. Some qualitative baseline characteristics were compared using the Fisher's Exact-Test.

Bivariate regression analysis was presented in a graphical form and Pearson's correlation coefficient was obtained.

Statistical significant was accepted, if the corresponding two-sided p-value was smaller or equal to 0.05 . Statistical analysis was performed with SPSS for Windows (Version 15.0).

\section{Table 1 Baseline clinical characterics of the study} population

\begin{tabular}{lccccc}
\hline & $\begin{array}{c}\text { IHD1 } \\
(\mathbf{n}=\mathbf{4 0})\end{array}$ & $\begin{array}{c}\text { IHD 2 } \\
(\mathbf{n}=\mathbf{4 0 )})\end{array}$ & $\begin{array}{c}\text { IHD 3 } \\
(\mathbf{n}=\mathbf{4 0})\end{array}$ & $\mathbf{P}$ & $\begin{array}{c}\text { Control } \\
\mathbf{G r o u p} \\
(\mathbf{n}=\mathbf{4 0})\end{array}$ \\
\hline Age & $60 \pm 15$ & $60 \pm 11$ & $64 \pm 10$ & NS & $66 \pm 10$ \\
male & 24 & 26 & 25 & NS & 21
\end{tabular}

Cardiovascular Risk Factors \% (n)

$$
\begin{aligned}
& \text { Hypertension } 80(n=32) 80(n=32) 78(n=31) \quad \text { NS } \\
& \text { Hyperlipidemia } 60(n=24) 60(n=24) 53(n=21) \quad N S \\
& \text { Smoking } 68(n=27) 75(n=30) 63(n=25) \quad N S \\
& \text { Positive family } 40(16) \quad 40(n=16) 35(n=14) \quad N S \\
& \text { history of CAD } \\
& \text { Diabetes } 20(n=8) 20(n=8) 60(n=24) p=0.001 \\
& \text { OHA } 15(n=6) 15(n=6) 45(n=18) \quad N S \\
& \text { Insulin } \quad 5(n=2) \quad 5(n=2) \quad 15(n=6) \quad N S
\end{aligned}
$$

Total number of CVRFs $\quad 4.2 \pm 0.8 \quad 4.3 \pm 0.8 \quad 4.4 \pm 0.9 \quad$ NS

$\begin{array}{llll}\text { Infarct-related vessel } \quad 19 / 8 / 13 & 20 / 10 / 11 & 20 / 8 / 12 & \text { NS }\end{array}$

(LAD/LCX/RCA)

\begin{tabular}{lccccc}
$\begin{array}{l}\text { PTCA/Stent at the } \\
\text { time of AMl }\end{array}$ & $40 / 40$ & $40 / 40$ & $40 / 40$ & NS & - \\
$\begin{array}{l}\text { Ejection fraction (\%) } \\
\text { Medication (\%) }\end{array}$ & $45 \pm 10$ & $43 \pm 11$ & $40 \pm 10$ & NS & $69 \pm 9$ \\
$\begin{array}{l}\text { Aspirin } \\
\text { Clopidogrel }\end{array}$ & 100 & 100 & 100 & NS & - \\
$\begin{array}{l}\text { ACE inhibitor or } \\
\text { AT Il blocker }\end{array}$ & 100 & 100 & 100 & NS & - \\
$\begin{array}{l}\text { Beta-blocker } \\
\text { Aldosterone Antagonist }\end{array}$ & 100 & 100 & 100 & NS & - \\
Statin & 100 & 25 & 100 & NS & - \\
\hline
\end{tabular}

Ischemic heart disease (IHD), Oral hypoglycaemic agent (OHA), Coronary artery disease (CAD), Percutaneous transluminal coronary angioplasty (PTCA), Creatine kinase (CK), Left anterior descending coronary artery (LAD), Left circumflex artery (LCX), Right coronary artery (RCA), Coronary artery disease (CAD), Cardiovascular risk factors (CVRFs), Acute myocardial infarction (AMI), None significant (NS). 


\section{Results}

Baseline characteristics of the patients and healthy control subjects

We included 120 patients with IHD and 40 healthy subjects without heart disease in the study. The baseline characteristics of the study population are depicted in Table 1. Although there was no significant difference in total number of CVRFs between all IHD patients groups, interestingly, there was a significant difference in the number of DM patients in IHD3 group compared to IHD1 and IHD2. In contrast, there was no significant difference in the number of DM patients between IHD1 and IHD2. Also no significant differences were observed in other baseline characteristics and demographics of patients between all IHD groups. No significant differences were observed in age and sex between all groups (Table 1).

\section{Functional activity of BM-CPCs}

The functional capacities of BM-CPCs were measured by migratory- and colony forming assay in 120 IHD patients as well as in 40 healthy subjects on day 1 of admission. The migratory response to stromal cell-derived factor 1 (SDF-1: $\mathrm{p}<0.001$ ) as well as vascular endothelial growth factor (VEGF: $\mathrm{p}<0001$ ) of BM-CPCs was impaired in patients with IHD compared to control group. Likewise, the colony-forming capacity (CFU-E: $p$ $<0.001$, CFU-GM: $p<0.001)$ was reduced in patients with IHD compared to control group. (Figure 1A and 1B) Furthermore, we found that the migratory -and colony forming capacities of BM-CPCs were significantly impaired in patients with IHD3 compared to IHD1 (VEGF: $\mathrm{p}<0.001$, SDF-1: $\mathrm{p}<0.001$; CFU-E: $\mathrm{p}<0.001$, CFU-GM: $\mathrm{p}<0.001$ ) and to IHD2 (VEGF: $\mathrm{p}=0.003$, SDF-1: $\mathrm{p}=0.003$; CFU-E: $\mathrm{p}=0.001$, CFU-GM: $\mathrm{p}=0.001$ ). In contrast, there were no significant differences in the functional activity of BM-CPCs between the patients with IHD2 and IHD1 (VEGF: $p=0.8$, SDF-1: $p=0.9$; CFU-E: $\mathrm{p}=0.1$, CFU-GM: $\mathrm{p}=0.1$ ). (Figure $2 \mathrm{~A}$ and 2B)

\section{Impact of DM on the functional activity of BM-CPCs in patients with IHD}

We investigated the correlation between DM $(n=40)$ and functional activity of BM-CPCs in patients with IHD. We observed a significant inverse correlation
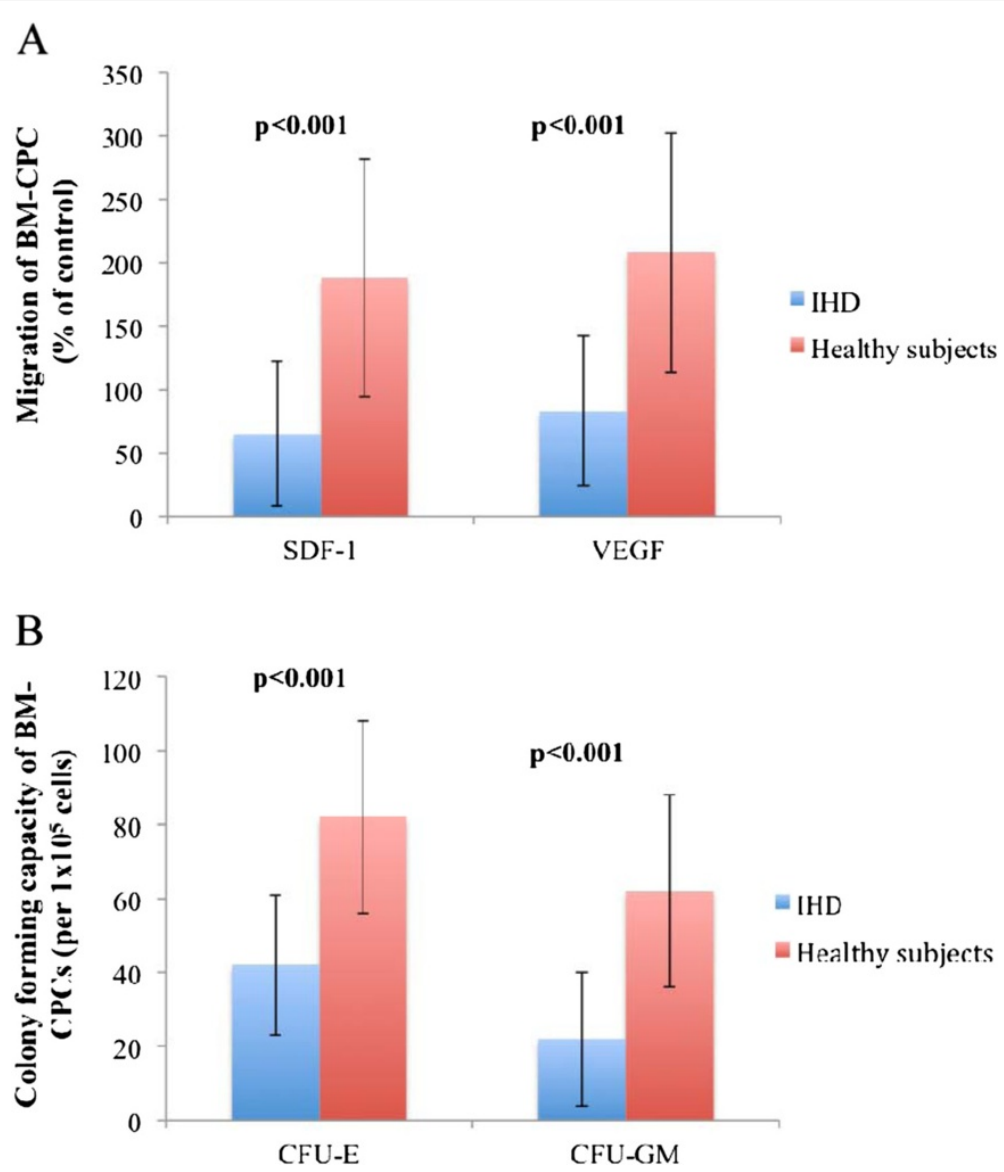

Figure $1 \mathrm{~A}$ and $\mathrm{B}$ : The colony-forming capacity and migratory response to stromal cell-derived factor 1 as well as vascular endothelial growth factor of BM-CPCs were reduced in patients with IHD compared to control group. 


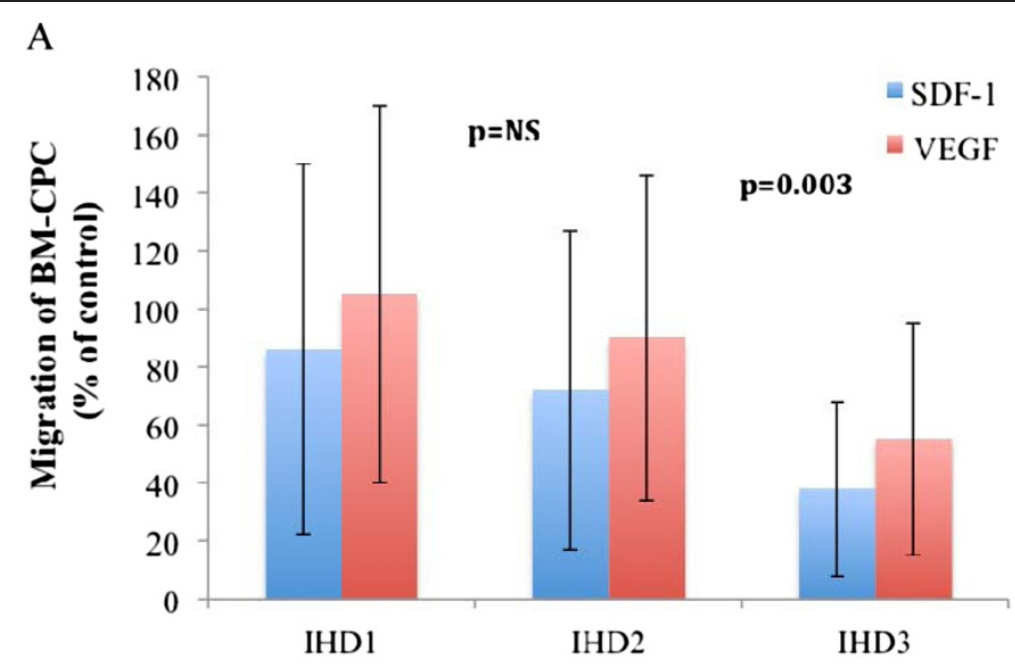

B

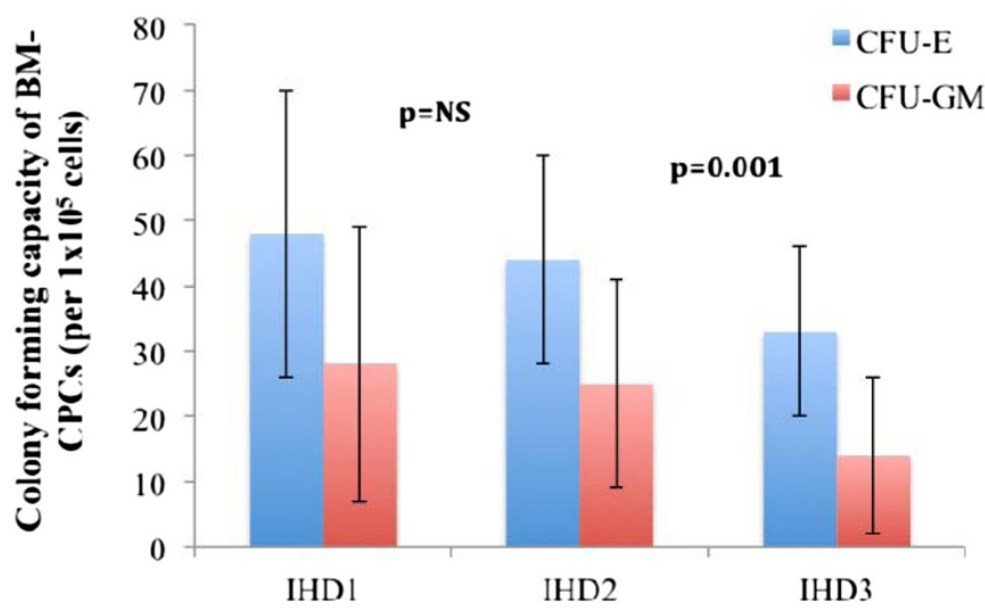

Figure $2 \mathrm{~A}$ and B: The migratory -and colony forming capacities of BM-CPCs were significantly impaired in patients with IHD3 compared to IHD1 and IHD2. In contrast, there were no significant changes in functional activity of BM-CPCs between the patients with IHD2 and IHD1.

between levels of HbA1c and the migratory (VEGF: p $<0.001, \mathrm{r}=-0.8$ SDF-1: $\mathrm{p}<0.001, \mathrm{r}=-0.8)$ and colony forming capacities (CFU-E: $p=0.001, r=-0.7, C F U-G M$ : $\mathrm{p}=0.001, \mathrm{r}=-0.6$ ) of BM-CPCs. (Figure 3. A, 3B, 4A and $4 \mathrm{~B})$ The functional activity of BM-CPCs was significantly reduced in DM patients with HbA1c $>7 \%(n=20)$ as compared to DM patients with HbA1c $<7 \%(n=20)$. (VEGF: $\mathrm{p}<0.001$, SDF-1: $\mathrm{p}<0.001$; CFU-E: $\mathrm{p}<0.001$, CFU-GM: $\mathrm{p}<0.001$ ) (Figure 5A and 5B)

\section{Discussion}

In this study we examined the influence of the number of diseased coronary arteries on the functional activity of BM-CPCs in patients with IHD.

Coronary artery disease results from a chronic inflammatory disease of the vascular wall and leads to vessel occlusion and organ damage. $[17,18]$ Despite intense efforts to determine the pathogenesis of atherosclerosis, this process remains poorly understood. Reports suggest that risk factors and a genetic predisposition together induce inflammatory processes that lead to cell damage and impair regeneration within the vessel wall. $[19,20]$ Since resident endothelial cells infrequently proliferate, [21] it has been postulated that there are other sources of vascular replenishment in response to continuous damage [22]. Circulating progenitor cells derived from bone marrow circulate in the peripheral blood and have been implicated in neoangiogenesis after tissue ischemia has occurred. [23-26] BM-CPCs is another population of progenitor cells that has also been shown to have therapeutic potential in the pool of progenitor cells circulating within the blood. BM-CPCs are capable of proliferating and differentiating into endothelial cells and are therefore ideal candidates for vascular 

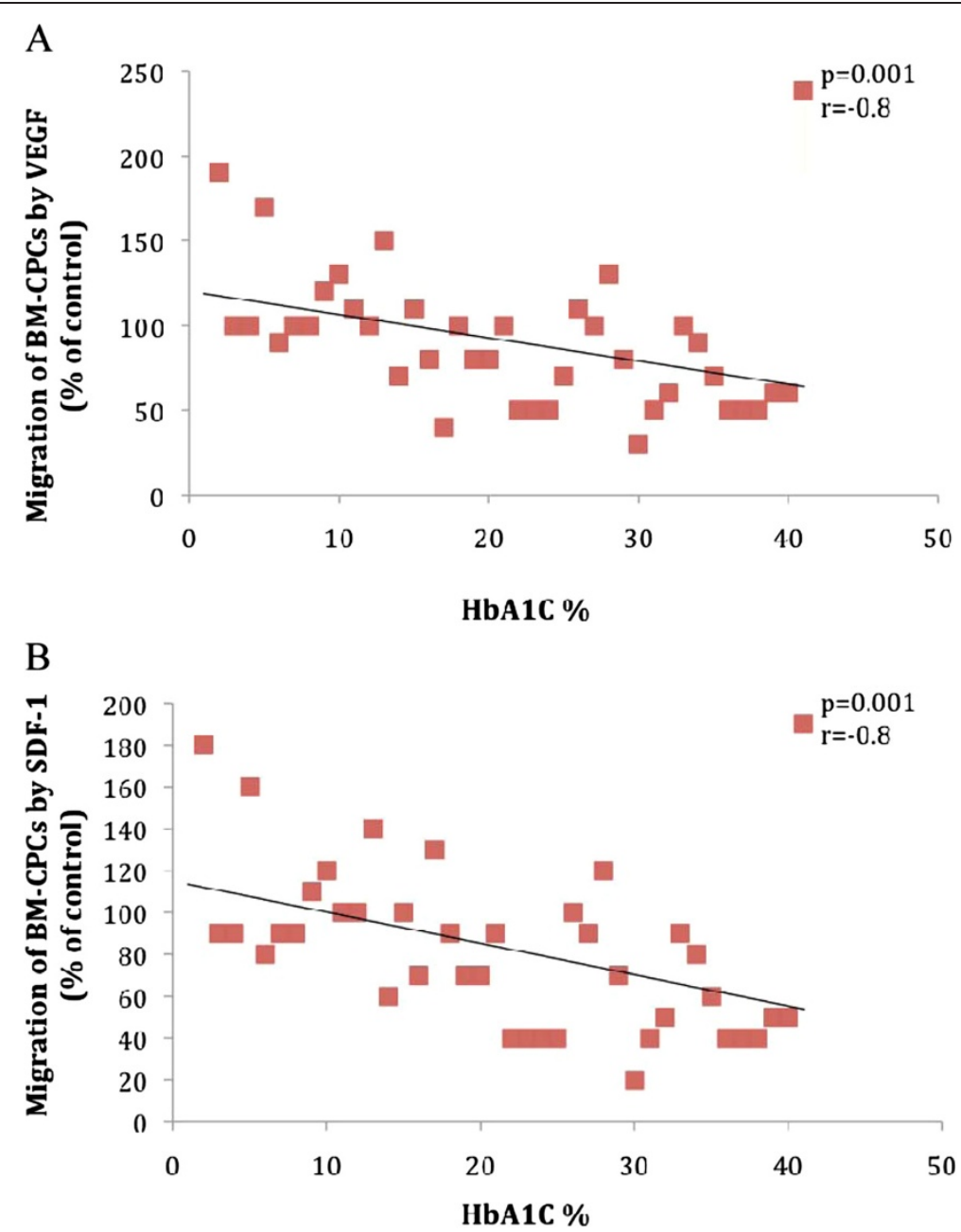

Figure $3 \mathrm{~A}$ and B: The migratory response to VEGF and SDF-1 correlates inverse to the level of HbA1c in patients with DM.

regeneration. [27,28] Experimental and clinical studies suggest that the systemic application or mobilization of stem cells and progenitor cells beneficially influences the repair of endothelial cells after injury and the progression of atherosclerosis. [29-35] Previous studies demonstrate that risk factors for coronary artery disease correlate with number and functional activity of BMCPCs. [8] Not only is the quantity of BM-CPCs altered, but their function is also modified by ischemic conditions and therapeutic interventions. [16] Migration is essential for the stem/progenitor cells to invade the ischemic tissue. SDF-1 and VEGF are both profoundly upregulated in hypoxic tissue $[36,37]$ and thus represent physiologically relevant chemoattractants for the recruitment of circulating progenitor cells to sites of ischemia. Indeed, intramuscular injection of the chemoattractant chemokine SDF-1 has recently been shown to increase the number of incorporated $\mathrm{BM}-\mathrm{CPCs}$ and to improve neovascularization in vivo. [38] Thus, the migratory response toward SDF-1 may indeed play a crucial role for integration of BM-CPCs in ischemic tissue. In addition, the accumulation of cardiovascular risk factors or an increased overall risk is associated with impaired colony forming activity of CPCs in healthy men. [9] Werner et al. [18] identified a significant association between increasing numbers and functional activities of BM-CPCs and decreased risk of major cardiovascular event and hospitalization in patients with coronary artery disease. In humans, a small-scale study suggests that there is a higher incidence of restenosis and revascularization in patients with reduced levels of BM-CPCs than in patients with increased numbers. [18,39] Recently we showed that Intracoronary transplantation of autologous BMCs may enhance and prolong the mobilisation as well as functional activity of BM-CPCs in PB in patients with ischemic heart disease and this might increase the regenerative potency in IHD. [40-42] Moreover, the mobilization of $\mathrm{CD} 34^{+}$and $\mathrm{CD} 133^{+} \mathrm{BM}-\mathrm{CPCs}$ is further impaired by DM in patients with IHD. [43,44] However, it is unknown whether the functional activity of BM- 

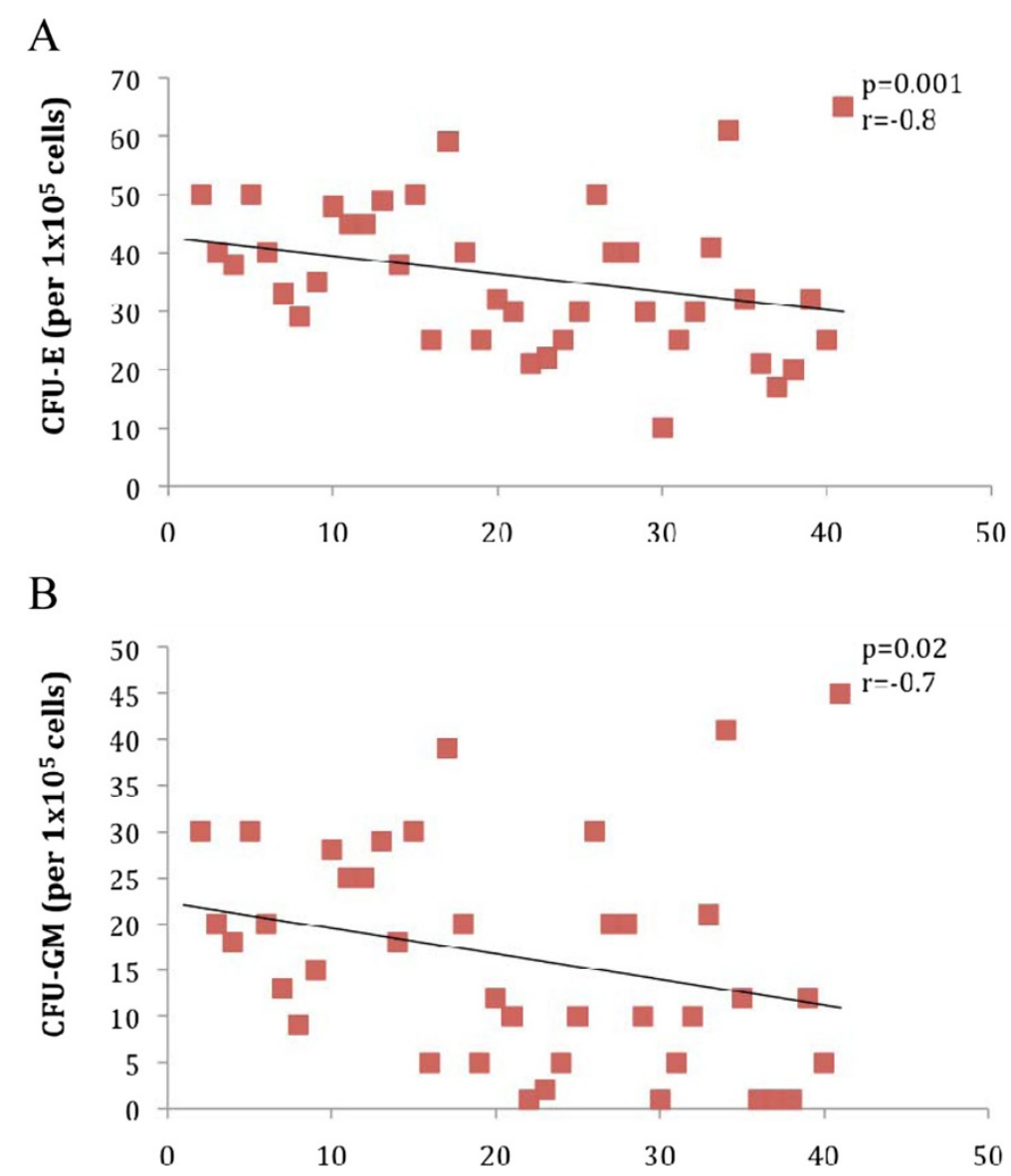

Figure $4 \mathrm{~A}$ and B: The colony forming capacitiy correlates inverse to the level of $\mathrm{HbA} 1 \mathrm{c}$ in patients with DM.

CPCs relates with the number of diseased coronary arteries in patients with IHD. We demonstrated in our study, that the functional activity of BM-CPCs was significantly impaired in patients with IHD3 compared to IHD2 and IHD1. Diabetes mellitus is associated with both an increased risk of atherosclerotic disease and poor outcome after vascular occlusion. The clinical severity of vascular occlusive disease in diabetics has in part been attributed to impaired collateral vessel development [45]. Extensive studies have shown that the numbers of circulating angiogenic cells are significantly lower in type II diabetes, and their angiogenic potential is also dramatically diminished. These cells display defective adhesion to the endothelium, reduced proliferation rate, and impaired ability to create new vascular structures. $[11,12,46]$ On the basis of these findings, it is tempting to speculate that the decrease of functional activity of BM-CPCs by DM leads to progression of atherosclerosis and increases the number of diseased coronary arteries in patients with IHD. In line with this hypothesis we observed in our study a significant higher incidence of DM in patients with IHD3 compared to IHD2 and IHD1. Furthermore, we demonstrated that the functional activity of BM-CPCs inversely correlated with the level of HbA1c in IHD patients with DM. The functional activity of BM-CPCs in DM patients with HbA1c $>7 \%$ was significantly reduced compared to DM patients with HbA1c $<7 \%$. Recent studies have shown that the PPARY agonist pioglitazone treatment increases the number and function of BM-CPCs in type $2 \mathrm{DM}$ patients with coronary artery disease. $[47,48]$ Improved levels of HbA1c by pharmacological therapy may lead to increase of BM-CPCs mobilization and functional activity and thereby may enhance the vascular regeneration in IHD patients with DM.

\section{Conclusion}

In the present study we could demonstrate that the functional activity of BM-CPCs was impaired in patients with IHD. This impairment correlates with increase of the number of diseased coronary arteries. Moreover, the regenerative capacity in ischemic tissue of BM-CPCs further declines in IHD patients with DM.

\section{Competing interests}

The authors have no competing interests to declare. 

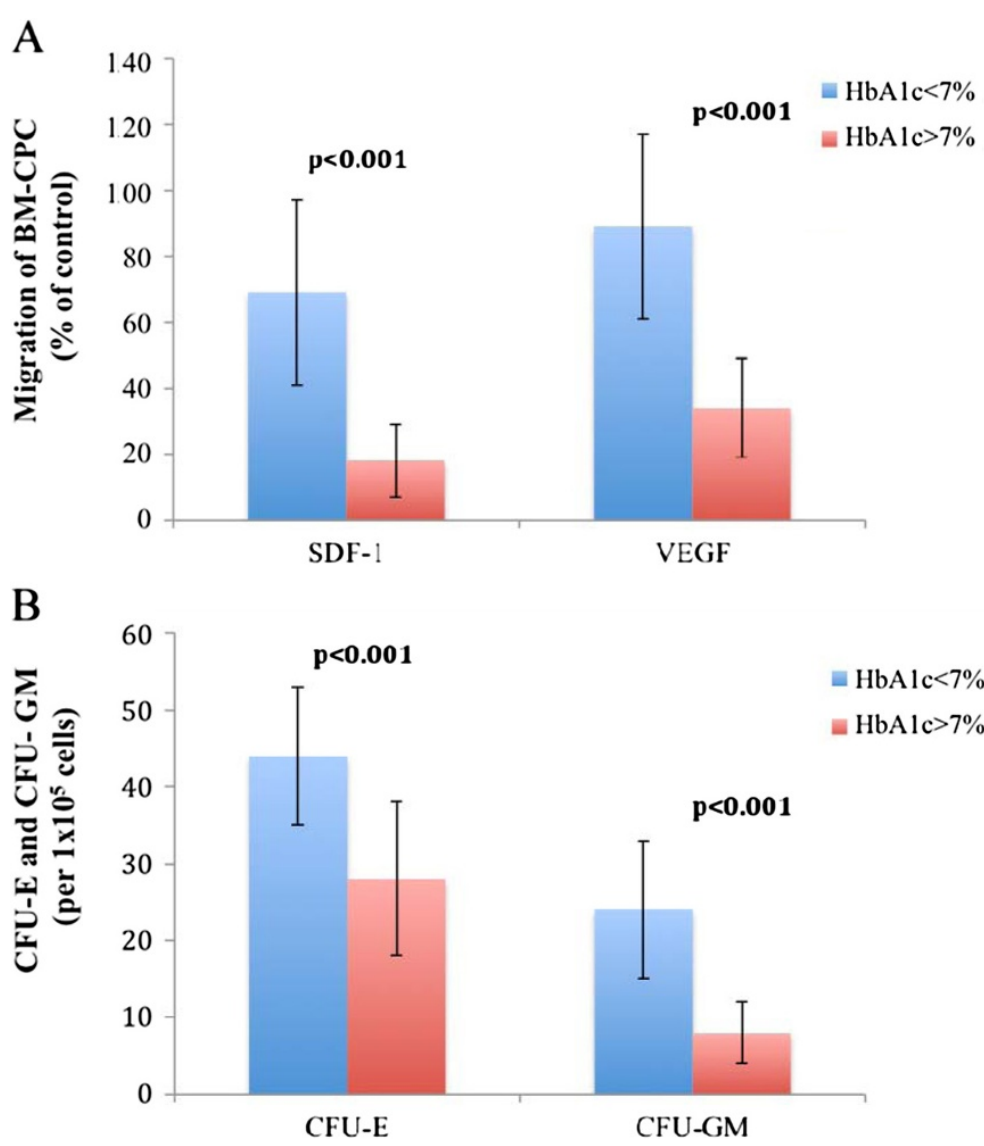

Figure $5 \mathrm{~A}$ and $\mathrm{B}$ : The migration and colony forming capacities of BM-CPCs are significantly reduced in patients with $\mathrm{HbA} 1 \mathrm{C}>7 \%$ compared to patients with $\mathrm{HbA} 1 \mathrm{c}<\mathbf{7 \%}$.

\section{Acknowledgements}

We thank Andrea Thesenvitz for the technical assistance.

\section{Author details}

${ }^{1}$ Department of Internal Medicine, Division of Cardiology, University hospital Rostock, Ernst Heydemann Str 6, Rostock 18055, Germany. ${ }^{2}$ Stem Cell Institute, Ankara University, Ankara, Turkey.

\section{Authors' contributions}

All authors have read and approved the final manuscript. The specific contributions of each author are; IBT, RGT and CAN conceived, designed and directed the entire study, interpreted all data and wrote the manuscript. LP, $\mathrm{NA}, \mathrm{CHT}, \mathrm{IA}, \mathrm{SK}, \mathrm{JO}, \mathrm{HS}, \mathrm{SL}, \mathrm{TH}, \mathrm{SD}, \mathrm{RA}, \mathrm{HI}$ and GA collected the preliminary data, participated in the study design, interpretation of the data, revision of paper.

Received: 8 March 2012 Accepted: 9 July 2012

Published: 9 July 2012

\section{References}

1. Luttun A, Carmeliet G, Carmeliet P: Vascular progenitors: from biology to treatment. Trends Cardiovasc Med 2002, 12:88-96.

2. Szmitko PE, Fedak PW, Weisel RD, Stewart DJ, Kutryk MJ, Verma S: Endothelial progenitor cells, new hope for a broken heart. Circulation 2003, 107:3093-3100.

3. Deschaseaux F, Pontikoglou C, Sensébé L: Bone regeneration: the stem/ progenitor cells point of view. J Cell Mol Med 2010, 14:103-115.

4. Timmermans F, Plum J, Yöder MC, Ingram DA, Vandekerckhove B, Case J: Endothelial progenitor cells: identity defined? J Cell Mol Med 2010, 13:87102
5. Asahara T, Masuda H, Takahashi T, Kalka C, Pastore C, Silver M, Kearne M, Magner M, Isner JM: Bone marrow origin of endothelial progenitor cells responsible for postnatal vasculogenesis in physiological and pathological neovascularization. Circ Res 1999, 85:221-228.

6. Takahashi T, Kalka C, Masuda H, Chen D, Silver M, Kearney M, Magner M, Isner JM, Asahara T: Ischemia-and cytokine-induced mobilization of bonemarrow-derived endothelial progenitor cells for neovascularization. Nat Med 1999, 5:434-438.

7. Hattori K, Heissig B, Tashiro K, Honjo T, Tateno M, Shieh JH, Hackett NR, Quitoriano MS, Crystal RG, Rafii S, Moore MA: Plasma elevation of stromal cell-derived factor-1 induces mobilization of mature and immature hematopoetic progenitor and stem cells. Blood 2001, 97:3354-3360.

8. Moore MA, Hattori K, Heissig B, Shieh JH, Dias S, Crystal RG, Rafii S: Mobilization of endothelial and hematopoietic stem and progenitor cells by adenovector-mediated elevation of serum levels of SDF-1, VEGF, and aniopoietin. Ann NY Acad Sci. 2001, 938:36-47.

9. Hill JM, Zalos G, Halcox JP, Schenke WH, Waclawiw MA, Quyyumi AA, Finkel $\mathrm{T}$ : Circulating endothelial progenitor cells, vascular function, and cardiovascular risk. N Engl J Med 2003, 348:593-600.

10. Vasa M, Fichtlscherer S, Aicher A, Adler K, Urbich C, Martin H, Zeiher AM, Dimmeler S: Number and migratory activity of circulating endothelial progenitor cells inversely correlate with risk factors for coronary artery disease. Circ Res 2001, 89:E1-E7.

11. Tepper OM, Galiano RD, Capla JM, Kalka C, Gagne PJ, Jacobowitz GR, Levine JP, Gurtner GC: Human endothelial progenitor cells from type II diabetics exhibit impaired proliferation, adhesion, and incorporation into vascular structures. Circulation 2002, 106:2781-2786.

12. Fadini GP, Sartore S, Albiero M, Baesso I, Murphy E, Menegolo M, Grego F, de Kreutzenberg Vigili S, Tiengo A, Agostini C, Avogaro A: Number and 
function of endothelial progenitor cells as a marker of severity for diabetic vasculopathy. Arterioscler Thromb Vasc Biol 2006, 26:2140-2146.

13. Li M, Takeneka H, Asai J, Ibusuki K, Mizukami Y, Maruyama K, Yoon YS, Wecker A, Luedemann C, Eaton E, Silver M, Thorne T, Losordo DW: Endothelial progenitor thrombospondin-1 mediates diabetes induced delay in reendothelialization following arterial injury. Circ Res 2006, 98:697-704.

14. Vita JA, Treasure CB, Nabel EG, McLenachan JM, Fish RD, Yeung AC, Vekshtein VI, Selwyn AP, Ganz P: Coronary vasomotor response to acetylcholine relates to risk factors for coronary artery disease. Circulation 1990, 81:491-497.

15. Scanlon PJ, Faxon DP, Audet AM, Carabello B, Dehmer GJ, Eagle KA, Legako RD, Leon DF, Murray JA, Nissen SE, Pepine CJ, Watson RM, Ritchie JL, Gibbons RJ, Cheitlin MD, Gardner TJ, Garson A Jr, Russell RO Jr, Ryan TJ, Smith SC Jr: ACC/AHA guidelines for coronary angiography: a report of the American College of Cardiology/American Heart Association Task Force on practice guidelines (Committee on Coronary Angiography): developed in collaboration with the Society for Cardiac Angiography and Interventions. J Am Coll Cardiol 1999, 33:1756-1824.

16. Heeschen C, Lehman R, Honold J, Assmus B, Aicher A, Walter DH, Martin H, Zeiher AM, Dimmeler S: Profoundly reduced neovascularization capacity of bone marrow mononuclear cells derived from patients with chronic ischemic heart disease. Circulation 2004, 109:1615-1622.

17. Ross R: Atherosclerosis an inflammatory disease. N Engl J Med 1999, 340:115-126.

18. Werner N, Kosiol S, Schiegl T, Ahlers P, Walenta K, Link A, Böhm M, Nickenig G: Circulating Endothelial Progenitor Cells and Cardiovascular Outcomes. N Engl J Med 2005, 353:999-1007.

19. Choy JC, Granville DJ, Hunt DW, McManus BM: Endothelial cell apoptosis: biochemical characteristics and potential implications for atherosclerosis. J Mol Cell Cardiol 2001, 33:1673-1690.

20. Gill M, Dias S, Hattori K, Rivera ML, Hicklin D, Witte L, Girardi L, Yurt R, Himel H, Rafii $\mathrm{S}$ : Vascular trauma induces rapid but transient mobilization of VEGFR2 (+) AC133(+) endothelial precursor cells. Circ Res 2001, 88:167-174.

21. Schwartz SM, Benditt EP: Clustering of replicating cells in aortic endothelium. Proc Natl Acad Sci U S A 1976, 73:651-653.

22. Opden Buiis J, Musters M, Verrips T, Post JA, Braam B, van Riel N: Mathematical modeling of vascular endothelial layer maintenance: the role of endothelial cell division, progenitor cell homing, and telomere shortening. Am J Physiol Heart Circ Physiol 2004, 287:H2651-H2658.

23. Asahara T, Murohara T, Sullivan A, Silver M, van der Zee R, Li T, Witzenbichler B, Schatteman G, Isner JM: Isolation of putative progenitor endothelial cells for angiogenesis. Science 1997, 275:964-967.

24. Kalka C, Masuda H, Takahashi T, Kalka-Moll WM, Silver M, Kearney M, Li T, Isner JM, Asahara T: Transplantation of ex vivo expanded endothelial progenitor cells for therapeutic neovascularization. Proc Natl Acad Sci U S A 2000, 97:3422-3427.

25. Kawamoto A, Gwon HC, Iwaguro H, Yamaguchi II, Uchida S, Masuda H, Silver M, Ma H, Kearney M, Isner JM, Asahara T: Therapeutic potential of ex vivo expanded endothelial progenitor cells for myocardial ischemia. Circulation 2001, 103:634-637.

26. Rafii S, Lyden D: Therapeutic stem and progenitor cell transplantation for organ vascularization and regeneration. Nat Med 2003, 9:702-712.

27. Gehling UM, Ergun S, Schumacher U, Wagener C, Pantel K, Otte M, Schuch G, Schafhausen P, Mende T, Kilic N, Kluge K, Schäfer B, Hossfeld DK, Fiedler W: In vitro differentiation of endothelial cells from AC133-positive progenitor cells. Blood 2000, 95:3106-3112.

28. Gunsilius E, Duba HC, Petzer AL, Kähler CM, Gastl GA: Contribution of endothelial cells of hematopoietic origin to blood vessel formation. Circ Res 2001, 88:E1.

29. Kong D, Melo LG, Gnecchi M, Zhang L, Mostoslavsky G, Liew CC, Pratt RE, Dzau VJ: Cytokine-induced mobilization of circulating endothelial progenitor cells enhances repair of injured arteries. Circulation 2004 110:2039-2046.

30. Nowak G, Karrar A, Holmen C, Nava S, Uzunel M, Hultenby K, SumitranHolgersson S: Expression of vascular endothelial growth factor receptor-2 or tie-2 on peripheral blood cells defines functionally competent cell populations capable of reendothelialization. Circulation 2004, 110:36993707.

31. Strehlow K, Werner N, Berweiler J, Link A, Dirnagl U, Priller J, Laufs K, Ghaeni L, Milosevic M, Böhm M, Nickenig G: Estrogen increases bone marrow- derived endothelial progenitor cell production and diminishes neointima formation. Circulation 2003, 107:3059-3065.

32. Walter DH, Rittig K, Bahlmann FH, Kirchmair R, Silver M, Murayama T, Nishimura H, Losordo DW, Asahara T, Isner JM: Statin therapy accelerates reendothelialization: a novel effect involving mobilization and incorporation of bone marrow-derived endothelial progenitor cells. Circulation 2002, 105:3017-3024.

33. Werner N, Priller J, Laufs U, Endres M, Böhm M, Dirnagl U, Nickenig G: Bone marrow-derived progenitor cells modulate vascular reendothelialization and neointimal formation: effect of 3-hydroxy-3-methylglutaryl coenzyme A reductase inhibition. Arterioscler Thromb Vasc Biol 2002, 22:1567-1572.

34. Werner N, Junk S, Laufs U, Link A, Walenta K, Bohm M, Nickenig G: Intravenous transfusion of endothelial progenitor cells reduces neointima formation after vascular injury. Circ Res 2003, 93:e17-e24.

35. Rauscher FM, Goldschmidt-Clermont PJ, Davis BH, Wang T, Gregg D, Ramaswami P, Pippen AM, Annex BH, Dong C, Taylor DA: Aging, progenitor cell exhaustion, and atherosclerosis. Circulation 2003, 108:457463.

36. Lee SH, Wolf PL, Escudero R, Deutsch R, Jamieson SW, Thistlethwaite PA: Early expression of angiogenesis factors in acute myocardial ischemia and infarction. N Eng J Med 2000, 342:626-633.

37. Pilarisetti K, Gupta SK: Cloning and relative expression analysis of rat stromal cell derived factor-1 (SDF-1) 1:SDF-1 alpha mRNA is selectively induced in rat model of myocardial infarction. Inflammation 2001, 25:293300.

38. Yamaguchi J, Kussano KF, Masuo O, Kawamoto A, Silver M, Murasawa S, Bosch-Marce M, Masuda H, Losordo DW, Isner JM, Asahara T: Stromal cellderived factor-1 effects on ex vivo expanded endothelial progenitor cell recruitment for ischemic neovascularization. Circulation 2003, 107:13221328.

39. George J, Herz I, Goldstein E, Abashidze S, Deutch V, Finkelstein A, Michowitz Y, Miller H, Keren G: Number and adhesive properties of circulating endothelial progenitor cells in patients with in-stent restenosis. Arterioscler Thromb Vasc Biol 2003, 23:e57-e60.

40. Turan RG, Bozdag-Turan I, Ortak J, Akin I, Kische S, Schneider H, Turan CH, Rehders TC, Rauchhaus M, Kleinfeldt T, Adolph E, Brehm M, Yokus S, Steiner S, Sahin K, Nienaber CA, Ince H: Improved mobilisation of the CD34+ and CD133+ bone marrow derived circulating progenitor cells by freshly isolated intracoronary bone marrow cells transplantation in patients with ischemic heart disease. Stem Cell and Dev 2011, 20 (9):1491-1501.

41. Turan RG, Bozdag-Turan I, Ortak J, Kische S, Akin I, Schneider H, Turan CH, Rehders TC, Rauchhaus M, Kleinfeldt T, Belu C, Brehm M, Yokus S, Steiner S, Sahin K, Nienaber CA, Ince H: Improved functional activity of bone marrow derived circulating progenitor cells after intra coronary freshly isolated bone marrow cells transplantation in patients with ischemic heart disease. Stem Cell Rev 2011, 7(3):646-656.

42. Turan RG, Bozdag-Turan I, Turan CH, Ortak J, Akin I, Kische S, Schneider H, Rauchhaus M, Rehders TC, Kleinfeldt T, Belu C, Amen S, Hermann T, Yokus S, Brehm M, Steiner S, Chatterjee T, Sahin K, Nienaber CA, Ince H: Enhanced mobilisation of the bone marrow derived circulating progenitor cells by intracoronary freshly isolated bone marrow cells transplantation in patients with acute myocardial infarction. J Cell Mol Med 2012, 16(4):852864.

43. Turan RG, Turan CH, Bozdag-Turan I, Ortak J, Akin I, Kische S, Schneider H, Kleinfeldt T, Rehders TC, Rauchhaus M, Adolph E, Amen S, Hermann T, Yokus S, Brehm M, Steiner S, Sahin K, Nienaber CA, Ince H: Impaired Mobilization of CD133(+) Bone Marrow-Derived Circulating Progenitor Cells With an Increased Number of Diseased Coronary Arteries in Ischemic Heart Disease Patients With Diabetes. Circ J 2011, 75(11):26352641.

44. Bozdag-Turan I, Turan RG, Turan CH, Ludovicy S, Akin I, Kische S, Arsoy NS, Schneider H, Ortak J, Rehders T, Hermann T, Paranskaya L, Kohlschein P, Bastian M, Ulus AT, Sahin K, Ince H, Nienaber CA: Relation between the frequency of $\mathrm{CD} 34^{+}$bone marrow derived circulating progenitor cells and the number of diseased coronary arteries in patients with myocardial ischemia and diabetes. Cardiovasc Diabetol 2011, 10:107.

45. Abaci A, Oguzhan A, Kahraman S, Eryol NK, Unal S, Arinç H, Ergin A: Effect of diabetes mellitus on formation of coronary collateral vessels. Circulation 1999, 99:2239-2242. 
46. Caballero S, Sengupta N, Afzal A, Chang KH, Li Calzi S, Guberski DL, Kern TS, Grant MB: Ischemic vascular damage can be repaired by healthy, but not diabetic, endothelial progenitor cells. Diabetes J 2007, 56:960-967.

47. Werner C, Kamani CH, Gensch C, Böhm M, Laufs U: The peroxisome proliferator-activated receptor-y agonist pioglitazone increases number and function of endothelial progenitor cells in patients with Coronary Artery Disease and normal glucose tolerance. Diabetes J 2007, 56:26092615.

48. Makino H, Okada S, Nagumo A, Sugisawa T, Miyamoto Y, Kishimoto I, Akie TK, Soma T, Taguchi A, Yoshimasa Y: Pioglitazone treatment stimulates circulating CD34-positive cells in type 2 diabetes patients. Diabetes Res Clin Pract 2008, 81:327-330

doi:10.1186/1479-5876-10-143

Cite this article as: Bozdag-Turan et al:: Correlation between the

functional impairment of bone marrow-derived circulating progenitor cells and the extend of coronary artery disease. Journal of Translational Medicine 2012 10:143.

\section{Submit your next manuscript to BioMed Central and take full advantage of:}

- Convenient online submission

- Thorough peer review

- No space constraints or color figure charges

- Immediate publication on acceptance

- Inclusion in PubMed, CAS, Scopus and Google Scholar

- Research which is freely available for redistribution 